\title{
Pengembangan Media Kubus Ajaib Menggunakan Grafik 3D GeoGebra untuk Meningkatkan Kemampuan Spasial Siswa
}

\author{
Wayan Subadre \\ SMP Negeri 3 Tanjung, Dinas Pendidikan Kepemudaan dan Olahraga, Lombok Utara \\ email: wyn.sbdr85@gmail.com
}

\begin{abstract}
Humans have special gift of unlimited intelligence. So far, the measure of intelligence always has been seen from IQ. This statement was contradicted by Howard Gardner who divided intelligence into eight types, one of that is spatial intelligence. This research focused on spatial ability problem. To solve the problem, researcher used Magic Cube Media which was developed by using Geogebra 3D Graphics software. The type of this research is Research and Development ( $\mathrm{RnD}$ ) with 4D Model (Define, Design, Develop and Disseminate). The product that the researcher developed was a Magic Cube Media using Geogebra 3D Graphics. The sample of this research were 30 students of SMPN 3 Tanjung in VIII-1 class and 30 students in VIII-2 class. The sample was selected by purposive sampling technique. The result showed that (1) Magic Cube Media was avowed as a valid media by the expert with the score of 90,28 as a very good category. (2) Magic Cube Media received a very positive response in the limited trial with the score of 85,34. (3) Magic Cube Media received a very positive response in the effectiveness test wth the score of 87,04. (4) Magic Cube Media was avowed effective in learning with the average difference of the score in experimental class and control class of 9,16. (5) Magic Cube media can improve students' spatial ability with average of 71,33.
\end{abstract}

Keywords: Magic Cube Media; Geogebra 3D Graphics; Spatial Ability

\begin{abstract}
Abstrak
Manusia memiliki anugerah istimewa berupa kecerdasan yang tidak terbatas. Selama ini ukuran kecerdasan selalu dilihat dari IQ. Pernyataan tersebut ditentang oleh Howard Gardner yang mengemukakan Intelegensi menjadi 8 jenis, salah satunya adalah kecerdasan spasial. Penelitian ini fokus terhadap masalah kemampuan spasial. Untuk menyelesaikan masalah tersebut, peneliti menggunakan Media Kubus Ajaib yang dikembangkan dengan menggunakan software Grafik 3D Geogebra. Jenis penelitian ini adalah Research and Development $(R \& D)$ dengan Model 4D yaitu Define, Design, Develop dan Disseminate. Adapun produk yang peneliti kembangkan adalah Media Kubus Ajaib Menggunakan Grafik 3D Geogebra. Sampel penelitian ini adalah siswa SMPN 3 Tanjung kelas VIII-1 sebanyak 30 orang dan kelas VIII-2 sebanyak 30 orang. Sampel dipilih dengan teknik purposive sampling. Hasil penelitian menunjukkan bahwa (1) Media Kubus Ajaib dinyatakan valid oleh ahli dengan nilai 90,28 kategori sangat baik; (2) Media Kubus Ajaib mendapatkan respons sangat positif dalam uji coba terbatas dengan nilai 85,34; (3) Media Kubus Ajaib mendapatkan respons sangat positif dalam uji efektivitas dengan nilai 87,04; (4) Media Kubus Ajaib dinyatakan efektif digunakan dalam pembelajaran dengan perbedaan selisih rata-rata nilai tes kelas eksperimen dan kelas kontrol 9,16; (5) Media Kubus Ajaib dapat meningkatkan kemampuan spasial siswa dengan rata-rata kemampuan spasial mencapai 71,33.
\end{abstract}

Kata Kunci: Media Kubus Ajaib; Grafik 3D GeoGebra; Kemampuan Spasial 


\section{PENDAHULUAN}

Manusia memiliki anugerah istimewa berupa kecerdasan yang tidak terbatas. Dengan adanya kecerdasan manusia lebih mudah dalam menyelesaikan permasalahan seharihari khususnya yang terkait dengan matematika. Namun, selama ini ukuran kecerdasan selalu dilihat dari Intelegence Quotient (IQ). Pernyataan tersebut ditentang oleh Howard Gardner, ia menegaskan bahwa skala kecerdasan yang selama ini dipakai ternyata memiliki banyak keterbatasan sehingga kurang dapat meramalkan kinerja sukses seseorang di masa depan, menurut Howard Gardner $I Q$ saja tidak cukup. Sehingga Howard mengemukakan Intelegensi menjadi 8 jenis (Multiple Intelegensi) salah satunya adalah kecerdasan spasial (Chatib, 2013). Konsep tentang berpikir spasial cukup menarik untuk dibahas mengingat banyak penelitian sebelumya yang menyatakan bahwa anak menemukan banyak kesulitan untuk memahami objek atau gambar bangun geometri.

Dari segi konteks matematika khususnya geometri ternyata kemampuan spasial sangat penting untuk ditingkatkan, hal ini mengacu dari hasil penelitian yang mengemukakan bahwa setiap siswa harus berusaha mengembangkan kemampuan dan penginderaan spasialnya yang sangat berguna dalam memahami relasi dan sifat-sifat dalam geometri untuk memecahkan masalah matematika. Pada tahun 2003 matematika merupakan domain penilaian utama PISA dan di dalamnya tercakup empat subdomain, yang salah satu diantaranya adalah kemampuan spasial siswa. Salah satu konten soal yang diteskan PISA kepada siswa adalah geometri. Pembelajaran geometri tidak terlepas dengan kemampuan spasial yang dimiliki siswa. Namun, kebanyakan siswa mengakui bahwa materi geometri di dalam matematika adalah salah satu materi yang sulit. Siswa banyak yang tidak menguasai materi geometri.

Berdasarkan hasil observasi peneliti pada siswa di SMP Negeri 3 Tanjung dimana siswa diminta untuk menyelesaikan soal berikut.

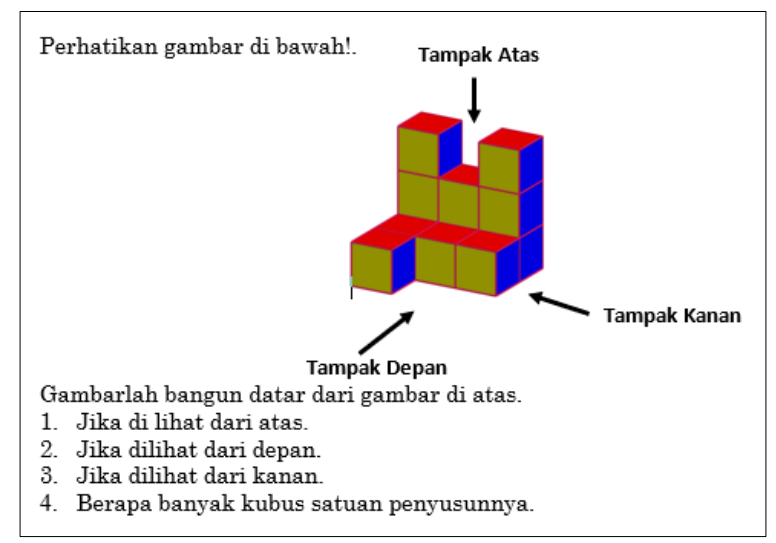

Gambar 1. Soal Tes Kemampuan Spasial Awal Siswa 
Beberapa jawaban siswa.

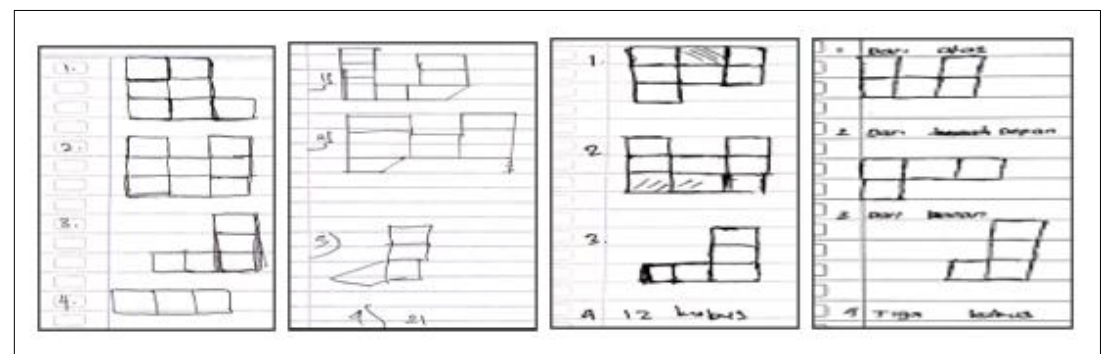

Gambar 2. Jawaban Siswa Hasil Tes Kemampuan Spasial Awal Siswa

Dari jawaban siswa hasil tes kemampuan spasial pada gambar 2 dapat disimpulkan bahwa kemampuan spasial siswa masih tergolong rendah. Data hasil tes awal kemampuan spasial siswa dapat dilihat pada tabel 1 berikut ini.

Tabel 1. Data Hasil Tes Awal Kemampuan Spasial Siswa

\begin{tabular}{clcc}
\hline No. & Deskriptif & Kelas VIII-1 & Kelas VIII-2 \\
\hline 1 & Jumlah Siswa & 30 & 30 \\
2 & Nilai Tertinggi & 80 & 85 \\
3 & Nilai Terendah & 25 & 25 \\
4 & Rata-Rata & 50,67 & 51,50 \\
\hline
\end{tabular}

Di sisi lain, proses pembelajaran penggunaan media semakin berkembang pesat, terutama di tingkat SMP penggunaan media komputer sudah dapat dilaksanakan. Untuk meningkatkan keefektifan pembelajaran, sekolah diharapkan menggunakan teknologi informasi dan komunikasi (ICT) seperti komputer, alat peraga, atau media lainnya. Materi yang disajikan dengan animasi akan membantu pemahaman materi serta belajar menjadi lebih menarik (Gunawan, 2015). Sejalan dengan itu, (Sardiman, 2014) menyatakan bahwa penggunaan media secara tepat dan bervariasi dapat mengatasi sifat pasif siswa dan memberi ruang kepada siswa untuk mengekplorasi diri. (Mudlofir \& Rusydiyah, 2016) juga menjelaskan bahwa media tidak hanya alat bantu, melainkan juga sebagai pembawa informasi sesuai dengan kebutuhan siswa. Berdasarkan dari hasil wawancara dengan beberapa siswa, banyak siswa mengatakan bahwa jika di dalam pembelajaran khususnya matematika menggunakan komputer, siswa akan merasa lebih tertarik untuk belajar. Namun pada kenyataannya, penggunaan media pembelajaran di dalam proses pembelajaran terutama berbantuan komputer masih sangat minim.

Berdasarkan uraian masalah di atas, peneliti fokus terhadap masalah kemampuan spasial. Untuk menyelesaikan masalah tersebut, peneliti mencoba menggunakan Media Kubus Ajaib yang dikembangkan dengan menggunakan software Grafik 3D Geogebra untuk meningkatkan kemampuan spasial siswa. Media Kubus Ajaib didesain dengan 
tujuan agar siswa terbantu dalam memahami perspektif geometri sehingga peneliti tertarik untuk melakukan penelitian dan pengembangan media pembelajaran untuk membantu siswa dalam meningkatkan kemampuan spasial siswa dengan judul "Pengembangan Media Kubus Ajaib Menggunakan Grafik 3D Geogebra Untuk Meningkatkan Kemampuan Spasial Siswa".

Berdasarkan paparan di atas, pertanyaan penelitian dapat dirumuskan sebagai berikut. (1) Bagaimana validitas Media Kubus Ajaib Menggunakan Grafik 3D Geogebra?; (2) Bagaimana respon siswa dalam uji terbatas Media Kubus Ajaib Menggunakan Grafik 3D Geogebra?; (3) Bagaimana efektivitas Media Kubus Ajaib Menggunakan Grafik 3D Geogebra itu dalam pembelajaran?; dan (4) Bagaimana peningkatan kemampuan spasial siswa pada pembelajaran geometri dengan menggunakan Media Kubus Ajaib Menggunakan Grafik 3D Geogebra?

\section{METODE}

Jenis penelitian ini adalah Research and Development (R\&D) atau Penelitian Pengembangan. Salah satu produk penelitian pengembangan adalah produk pendidikan. Produk pendidikan ini tidak terbatas pada produk berbentuk fisik seperti buku teks, namun bisa juga berupa software dan model pembelajaran. Adapun produk yang peneliti kembangkan adalah Media Kubus Ajaib Menggunakan Grafik 3D Geogebra, yaitu Media Kubus Ajaib yang dapat dijalankan menggunakan perangkat komputer dengan menggunakan Aplikasi Geogebra. Untuk mempermudah dan menyederhanakan tulisan, jika ditulis Media Kubus Ajaib maka yang dimaksud adalah Media Kubus Ajaib Menggunakan Grafik 3D Geogebra. Prosedur penelitian yang dimaksud dalam penelitian ini adalah model penelitian yang mempunyai langkah-langkah baku. Banyak model penelitian yang dikemukakan oleh para ahli. Peneliti memilih model yang dikemukakan oleh Thiagarajan, yang disebut Four D Models (Model 4D), yaitu Define (Pendefinisian), Design (Perancangan), Develop (Pengembangan) dan Disseminate (Penyebaran) (Sanjaya, 2015).

Populasi dalam penelitian ini adalah siswa SMPN 3 Tanjung kelas VIII tahun pelajaran 2019/2020. Adapun sampel penelitian ini adalah siswa SMPN 3 Tanjung kelas VIII-1 sebanyak 30 orang dan kelas VIII-2 sebanyak 30 orang. Sampel dipilih dengan teknik purposive sampling. Validasi Media Kubus Ajaib dilakukan oleh ahli media, ahli materi dan ahli praktisi. Untuk itu diperlukan instrumen lembar validasi. Lembar validasi terdiri dari 4 kolom jawaban atau penilaian, yang terdiri SB (Sangat Baik), B (Baik), TB (Tidak Baik) dan STB (Sangat Tidak Baik). Lembar validasi juga dilengkapi kolom komentar, saran dan kritik. Lembar validasi ini diisi oleh 3 orang ahli, yaitu ahli media, ahli materi dan ahli praktisi. Kualitas Media Kubus Ajaib perlu dinilai oleh siswa. Untuk 
melakukan penilaian itu menggunakan angket, yang disebut angket respon siswa. Angket ini menggunakan skala likert, yaitu SS (Sangat Setuju), S (Setuju), TS (Tidak Setuju) dan STS (Sangat Tidak Setuju). Setelah Media Kubus Ajaib divalidasi oleh ahli, selanjutnya digunakan dalam pembelajaran. Untuk mengetahui respons siswa diperlukan instrumen menggunakan angket. Angket ini menggunakan skala likert, yaitu SS (Sangat Setuju), S (Setuju), TS (Tidak Setuju) dan STS (Sangat Tidak Setuju). Wawancara dilakukan dengan tujuan untuk melakukan eksplorasi terhadap pemikiran siswa dan mendapatkan klarifikasi serta menilai tingkat pemahaman siswa melalui pertanyaan-pertanyaan terbuka dengan kerangka umum pertanyaan sebagai berikut: (1) Coba kamu jelaskan apa yang kamu pahami tentang gambar pada soal nomor 1?. (2) Jelaskan bagaimana cara menentukan tampak depan, kanan, dan atas dari gambar tersebut?. (3) Bagaimana cara kamu membuktikan bahwa kesimpulan tersebut sudah benar?. (4) Ketika kamu menemukan kesulitan dalam menyelesaikan permasalahan itu, apa yang kamu lakukan?. (5) Dalam mengerjakan soal itu, mana yang lebih kamu sukai mengerjakan sendiri atau berdiskusi dalam kelompok?. Jelaskan alasanmu?.

Untuk mengetahui kemampuan spasial siswa, maka perlu dilakukan tes kemampuan spasial. Untuk itu diperlukan instrumen berupa soal tes kemampuan spasial siswa. Hasil tes ini digunakan untuk mengukur peningkatan kemampuan spasial siswa setelah dilakukan pembelajaran menggunakan Media Kubus Ajaib.

Setelah divalidasi oleh ahli dan diujicobakan dalam lingkup terbatas, selanjutnya dilakukan uji coba dalam kegiatan pembelajaran di kelas sebenarnya. Dalam hal ini menggunakan model penelitian eksperimen, dengen jenis Pre-Experimental Design, dengan rancangan Intact-Group Comparison. Pada desain ini, terdapat kelompok sebagai kelas eksperimen dan kelompok sebagai kelas kontrol (Sugiyono, 2015). Sampel tidak dipilih secara random. Adapun desain penelitian adalah sebagai berikut.

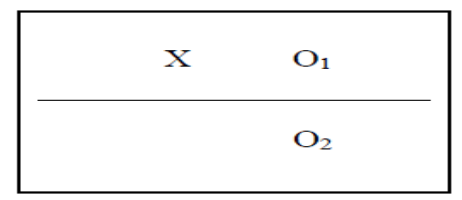

Gambar 3. Desain Penelitian

O1 adalah rerata tes hasil belajar kelas kontrol.

O2 adalah rerata tes hasil belajar kelas eksperimen.

Analisis datanya tidak menggunakan statistik inferensial seperti uji t, tetapi menggunakan statistik deskriptif (Sugiyono, 2015). Untuk mengukur pengaruh perlakuan digunakan rumus (O2-O1).

Data hasil wawancara dianalisis melalui pengamatan terhadap dokumen hasil 
wawancara dan pencatatan pola hasil pekerjaan siswa yang disajikan dalam bentuk naratif. Untuk mengetahui kemampuan spasial siswa, hasil tes kemampuan spasial siswa dianalisis secara deskriptif yaitu dengan menentukan nilai rata-rata hasil tes.

\section{HASIL DAN PEMBAHASAN}

Hasil penelitian yang diperoleh melalui tahapan 4D, yaitu yaitu Define, Design, Develop dan Disseminate adalah sebagai berikut.

\subsection{Define (Pendefinisian)}

Letak geografis SMPN 3 Tanjung terletak di dusun karang sobor kurang lebih $1 \mathrm{~km}$ ke arah selatan dari Kantor Desa Sokong Kecamatan Tanjung. Kondisi sosial masyarakat di sekitar lingkungan sekolah sangatlah heterogen. Mereka terbangun atas komunitas pegawai negeri sipil (PNS), wiraswasta, pedagang, petani, buruh dan ada pula yang pengangguran (berpenghasilan tidak tentu). Dengan demikian berimplikasi pula pada keberagaman tingkat ekonominya, yakni dari tingkat ekonomi mampu, kurang mampu atau tidak mampu sehingga perlu adanya subsidi silang pembiayaan di antara mereka dengan peran serta pemerintah daerah maupun pusat melalui regulasi/kebijakan yang ditetapkan, yakni menempatkan upaya mutu pendidikan sebagai program yang utama dan pertama. Namun demikian, warga sekitar sekolah sudah mengenal dan mau memanfaatkan kehadiran ilmu pengetahuan dan tekhnologi (IPTEK) demi mendapatkan informasi faktual yang semakin mengglobal dan cepat tersebar luas. Hal ini ditunjukkan dengan hadirnya pelayanan jasa dibidang informasi dan tekhnologi seperti: smartphone, internet sekolah, warnet dan sebagainya.

Perkembangan IPTEK di era globalisasi telah mempercepat proses kemajuan IPTEK sehingga kehidupan masyarakat Kecamatan Tanjung telah bergerak dengan lompatanlompatan dahsyat dalam kehidupannya. Kehidupan masyarakat yang terus menerus mengalami perubahan sebagai akibat dari kemajuan IPTEK menuntut SMPN 3 Tanjung untuk menyesuaikan serta mengantisipasi setiap kemajuan dan perubahan yang terjadi. Dengan perkembangan tersebut materi dan pengalaman belajar yang diajarkan di SMPN 3 Tanjung harus bermakna dan bermanfaat untuk bekal kehidupan siswa. Di samping itu, siswa SMPN 3 Tanjung hampir semua sudah mengenal dan mampu mengoperasikan komputer. Dalam kegiatan pembelajaran di kelas, sebagian besar guru sudah mampu menggunakan Laptop dan LCD Proyektor dalam menyampaikan materi pembelajaran. Hal ini akan memperkuat potensi SMPN 3 Tanjung untuk dapat dikembangkannya media pembelajaran berbasis IT berupa Media Kubus Ajaib.

Sebagai acuan dan kriteria dalam menetapkan keberhasilan sekolah sebagai penyelenggaraan pendidikan adalah Peraturan Pemerintah Republik Indonesia Nomor 


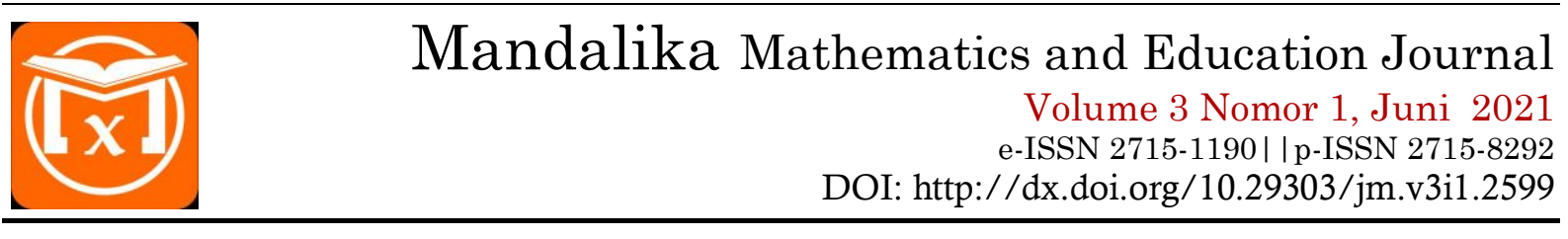

32 tahun 2013 tentang Perubahan atas Peraturan Pemerintah Nomor 19 tahun 2005 tentang Standar Nasional Pendidikan. Pada peraturan tersebut telah ditetapkan delapan standar nasional pendidikan, yaitu standar isi, standar proses, standar kompetensi lulusan, standar pendidik dan tenaga kependidikan, standar sarana dan prasarana, standar pengelolaan, standar pembiayaan, dan standar penilaian pendidikan. Namun, implementasi dari peraturan pemerintah tersebut masih dirasa belum maksimal. Hasil analisis sehubungan dengan hasil evaluasi diri sekolah (EDS) di SMPN 3 Tanjung tempat peneliti bertugas sebagai guru mata pelajaran matematika, masih ada kelemahan terutama pada standar Proses, sehingga berkonsekuensi belum terpenuhinya SNP atau dengan kata lain masih dalam kategori SPM, hal tersebut bisa dilihat pada gambar di bawah ini.

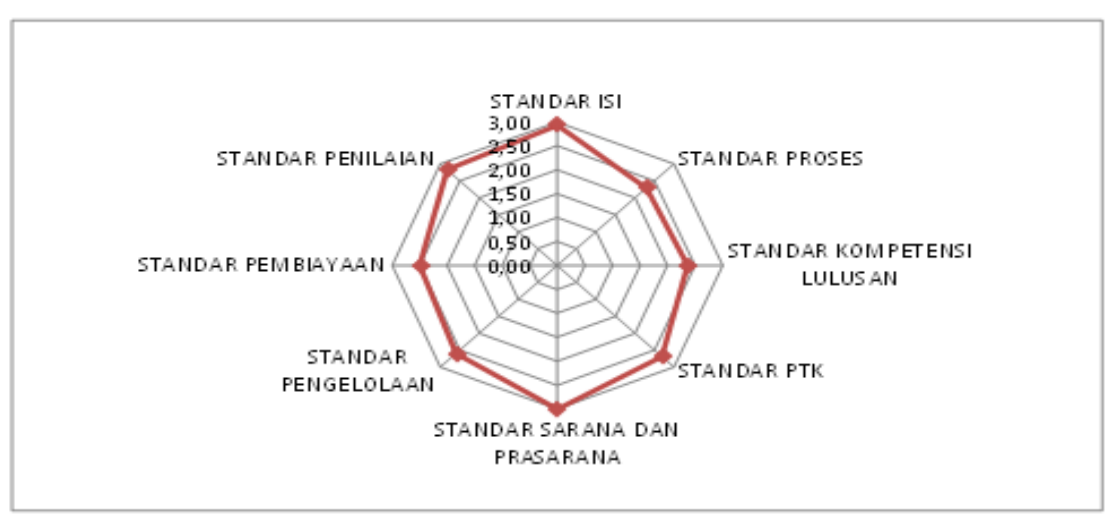

Gambar 4. Mutu Pendidikan berdasarkan EDS SMPN 3 Tanjung Tahun 2019

Berdasarkan uraian yang terkait dengan rendahnya mutu standar Proses terutama tentang Pembuatan Media Pembelajaran, maka peneliti terdorong untuk mengembangkan media pembelajaran berupa Media Kubus Ajaib yang dapat digunakan sebagai media pembelajaran matematika.

Analisis kurikulum juga sangat penting dilakukan. Analisis ini berguna untuk memenuhi kebutuhan dalam pengembangan Media Kubus Ajaib. Analisis kurikulum yang dimaksud adalah analisis KD (Kompetensi Dasar). KD yang peneliti ambil untuk pengembangan Media Kubus Ajaib ini adalah KD 4.9. Menyelesaikan masalah yang berkaitan dengan luas permukaan dan volume bangun ruang sisi datar (kubus, balok, prima dan limas), serta gabungannya. KD tersebut digunakan sebagai dasar untuk mendesain tampilan kubus untuk mengembangkan Media Kubus Ajaib. Di samping itu, KD tersebut juga digunakan untuk mengembangkan Lembar Kerja Peserta Didik (LKPD) sebagai lembar kerja siswa dalam menggunakan Media Kubus Ajaib. 


\subsection{Design (Perancangan)}

IPK (Indikator Pencapaian Kompetensi) perlu dirumuskan terlebih dahulu. Adapun IPK dapat dirumuskan sebagai berikut : (a) Menyelesaikan masalah yang berkaitan dengan kubus dan unsur-unsurnya melalui kegiatan eksplorasi media kubus ajaib; (b) Mengkonstruksi objek menggunakan kubus satuan melalui kegiatan eksplorasi media kubus ajaib; (c) Memanipulasi objek dari berbagai perspektif melalui kegiatan eksplorasi media kubus ajaib. Setelah IPK sudah ditentukan, langkah berikutnya adalah membuat desain antar muka Media Kubus Ajaib. Secara umum, kegiatan pembelajaran terdiri dari 2 kegiatan yaitu kegiatan pembelajaran 1 dan kegiatan pembelajaran 2 . Adapun desain antar muka Media Kubus Ajaib adalah sebagai berikut.

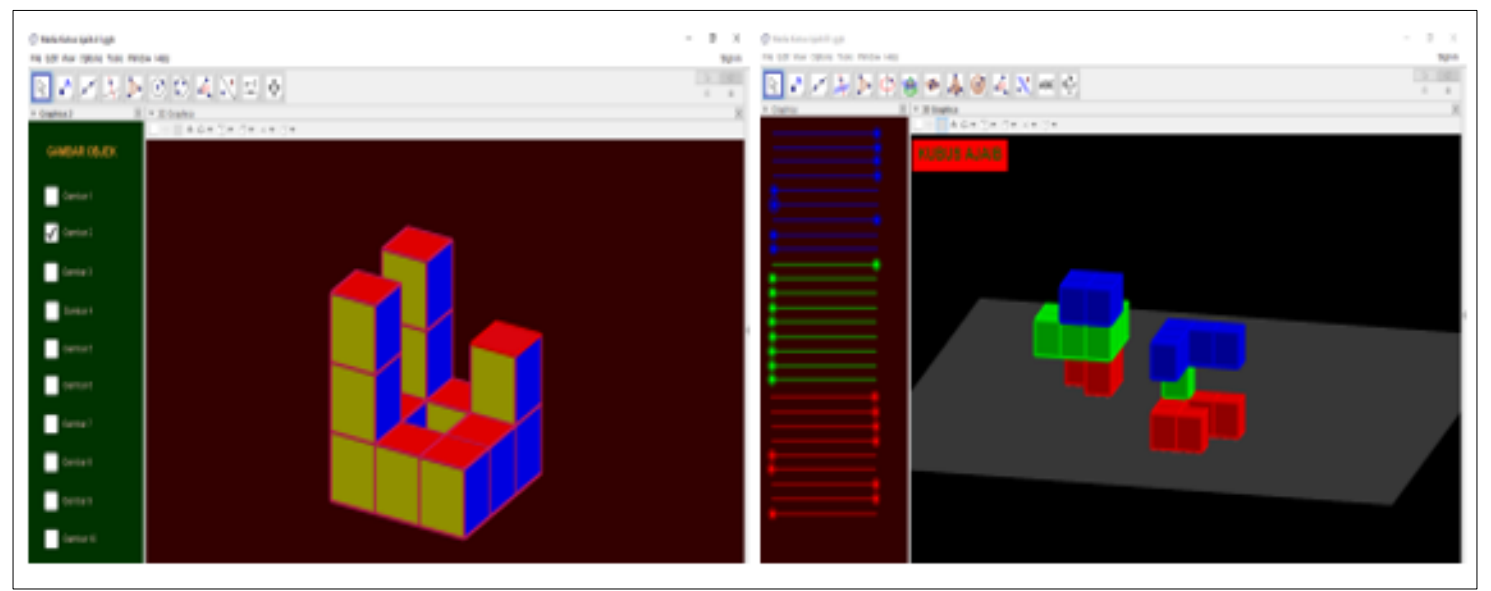

Gambar 5. Desain Antar Muka Media Kubus Ajaib

\subsection{Develop (Pengembangan)}

Banyak aplikasi komputer yang dapat digunakan dalam mendesain media pembelajaran berbasis IT yang kita inginkan sesuai dengan jenis medianya. Pembuatan Media Kubus Ajaib ini menggunakan aplikasi Grafik 3D Geogebra. Dengan memanfaatkan tools yang disediakan pada aplikasi Geogebra memungkinkan peneliti merancang Media Kubus Ajaib. Media Kubus Ajaib yang dibuat terdiri dari 2 file berekstensi .ggb. Untuk membuka dan menggunakan Media Kubus Ajaib ini diperlukan aplikasi Geogebra yang dapat didownload melalui tautan di bawah ini.

\section{https://www.geogebra.org/download}

Media Kubus Ajaib dan Panduan Penggunaan serta LKPD telah peneliti unggah di Google Drive pribadi peneliti, yang dapat diakses melalui tautan di bawah ini. https://drive.google.com/drive/folders/105jo-dy_fx7Q1UoH_kMYlsWIvWGn_7zn Media Kubus Ajaib dapat pula diakses langsung secara online pada link berikut. a). Media Kubus Ajaib A1 pada link https://www.geogebra.org/classic/cpwknrtk 
b). Media Kubus Ajaib B1 pada link https://www.geogebra.org/classic/zyvewkq5

Untuk keabsahan Media Kubus Ajaib ini diperlukan validasi yang dilakukan oleh para ahli. Para ahli yang memvalidasi terdiri dari 3 ahli, yaitu ahli media, ahli materi dan ahli praktisi. Adapun hasil validasi adalah sebagai berikut.

Tabel 2. Daftar Nilai Hasil Validasi Media Kubus Ajaib

\begin{tabular}{ccc}
\hline No. & Validator & Hasil \\
\hline 1 & Ahli Media & 91,67 \\
2 & Ahli Materi & 91,67 \\
3 & Ahli Praktisi & 87,50 \\
\hline
\end{tabular}

Dari tabel 2 didapat nilai rata-rata validasi 90,28 dengan predikat sangat baik. Dengan demikian Media Kubus Ajaib layak untuk digunakan. Setelah Media Kubus Ajaib divalidasi oleh ahli dan dinyatakan minimal baik, langkah selanjutnya dilakukan uji terbatas. Untuk itu Media Kubus Ajaib diujikan di kelas VIII-3 dengan jumlah responden 29 orang.

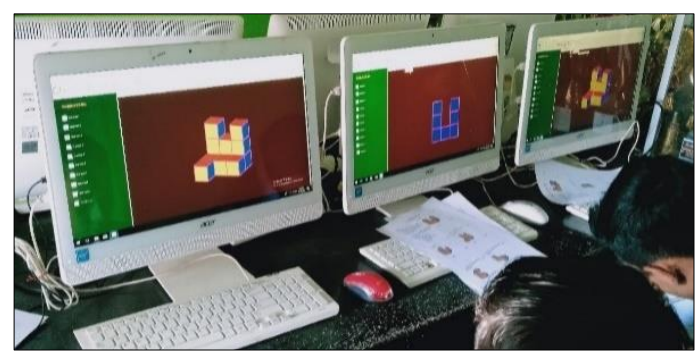

Gambar 6 Pelaksanaan Ujicoba Terbatas

Setelah siswa selesai mengikuti uji coba terbatas, siswa diberikan angket dengan jumlah pertanyaan 10 item. Hasil pengisian angket itu direkapitulasi sebagai berikut. 
Tabel 3. Hasil Analisis Angket Respons siswa Terhadap Media Kubus Ajaib

\begin{tabular}{|c|c|c|c|c|c|c|c|c|c|}
\hline \multirow{2}{*}{ No } & \multirow{2}{*}{ Pernyataan } & \multicolumn{2}{|c|}{ SS (4) } & \multicolumn{2}{|c|}{ S (3) } & \multicolumn{2}{|c|}{$\mathrm{TS}(2)$} & \multicolumn{2}{|c|}{ STS (1) } \\
\hline & & $\sum$ & $\%$ & $\sum$ & $\%$ & $\sum$ & $\%$ & $\sum$ & $\%$ \\
\hline 1 & $\begin{array}{l}\text { Tampilan Media Kubus Ajaib menarik } \\
\text { sehingga saya penasaran untuk segera } \\
\text { mencobanya }\end{array}$ & 10 & 34 & $\overline{19}$ & 66 & 0 & 0 & 0 & 0 \\
\hline 2 & $\begin{array}{l}\text { Media Kubus Ajaib sesuai dengan } \\
\text { materi yang disajikan }\end{array}$ & 7 & 24 & 20 & 69 & 2 & 7 & 0 & 0 \\
\hline 3 & $\begin{array}{l}\text { Media Kubus Ajaib mudah digunakan } \\
\text { untuk eksplorasi geometri }\end{array}$ & 15 & 52 & 11 & 38 & 3 & 10 & 0 & 0 \\
\hline 4 & $\begin{array}{l}\text { Instruksi/petunjuk penggunaan Media } \\
\text { Kubus Ajaib dapat dimengerti }\end{array}$ & 13 & 45 & 15 & 52 & 1 & 3 & 0 & 0 \\
\hline 5 & $\begin{array}{l}\text { Visualisasi dan animasi Media Kubus } \\
\text { Ajaib sesuai dengan indikator } \\
\text { pembelajaran }\end{array}$ & 16 & 55 & 13 & 45 & 0 & 0 & 0 & 0 \\
\hline 6 & $\begin{array}{l}\text { Animasi Media Kubus Ajaib cukup } \\
\text { beragam }\end{array}$ & 9 & 31 & 20 & 69 & 0 & 0 & 0 & 0 \\
\hline 7 & $\begin{array}{l}\text { Media Kubus Ajaib dapat membantu } \\
\text { melatih keterampilan dan penalaran } \\
\text { tentang geometri. }\end{array}$ & 15 & 52 & 13 & 45 & 0 & 0 & 1 & 3 \\
\hline 8 & $\begin{array}{l}\text { Media Kubus Ajaib menarik untuk } \\
\text { digunakan dari awal hingga akhir } \\
\text { pembelajaran }\end{array}$ & 12 & 41 & 16 & 55 & 0 & 0 & 1 & 3 \\
\hline 9 & $\begin{array}{l}\text { Media Kubus Ajaib dapat digunakan } \\
\text { sebagai alternatif media belajar materi } \\
\text { geometri dengan cara menyenangkan. }\end{array}$ & 18 & 62 & 11 & 38 & 0 & 0 & 0 & 0 \\
\hline 10 & $\begin{array}{lrr}\begin{array}{l}\text { Media } \\
\text { meningkatkan } \\
\text { matematika }\end{array} & \begin{array}{r}\text { Ajaib } \\
\text { motivasi }\end{array} & \begin{array}{r}\text { dapat } \\
\text { belajar }\end{array} \\
\end{array}$ & 17 & 59 & 11 & 38 & 0 & 0 & 1 & 3 \\
\hline Jum & ah Skor & 528 & & 447 & & 12 & & 3 & \\
\hline Tota & Skor & & & & & & & & \\
\hline Skor & Maksimum & & & & & & & & \\
\hline Nila & & & & & & & & & \\
\hline
\end{tabular}

Jika diperhatikan tabel 3 maka nilai 85,34 termasuk predikat sangat positif. Jadi dapat disimpulkan respons siswa terhadap Media Kubus Ajaib adalah sangat positif. Untuk melihat efektivitas penggunaan Media kubus Ajaib, pembelajaran dilakukan di kelas kontrol dan kelas eksperimen. Kelas kontrol tidak menggunakan Media Kubus Ajaib sedangkan kelas eksperimen menggunakan Media Kubus Ajaib. Kelas kontrol dipilih kelas VIII-2 sedangkan kelas eksperimen dipilih kelas VIII-1. Gambar 7 menunjukkan pelaksanaan pembelajaran di kelas kontrol dan di kelas eksperimen. 

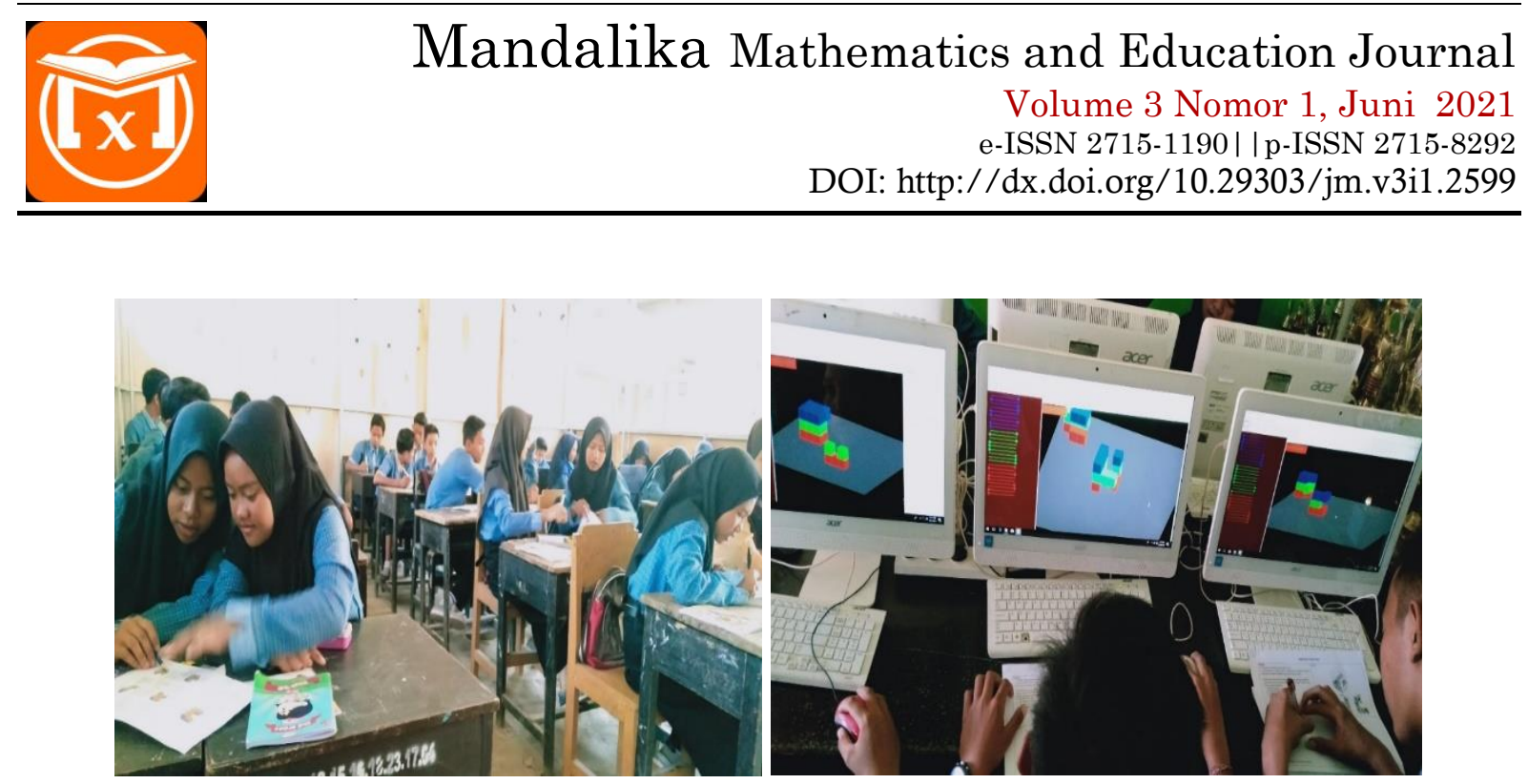

Gambar 7. Kegiatan Pembelajaran di Kelas Kontrol dan Kelas Eksperimen

Pada akhir kegiatan pembelajaran dilakukan tes kemampuan spasial, baik pada kelas kontrol maupun kelas eksperimen. Hasilnya dianalisis dengan menggunakan analisis statistik deskriptif, yaitu menentukan rata-rata nilai tes kelas kontrol dan kelas eksperimen. Berikut ini adalah nilai hasil tes kelas kontrol dan kelas eksperimen.

Tabel 4. Daftar Nilai Hasil Tes Kemampuan Spasial Akhir Siswa Kelas Kontrol dan Kelas Eksperimen

\begin{tabular}{clcc}
\hline No. & Deskriptif & Kelas Kontrol & Kelas Eksperimen \\
\hline 1 & Jumlah Siswa & 30 & 30 \\
2 & Nilai Tertinggi & 100 & 100 \\
3 & Nilai Terendah & 35 & 45 \\
4 & Rata-Rata & 62,17 & 71,33 \\
\hline
\end{tabular}

Berdasarkan tabel 4 diketahui rata-rata nilai tes kelas kontrol adalah 62,17 sedangkan rata-rata nilai tes kelas eksperimen adalah 71,33. Rata-rata nilai tes kelas eksperimen lebih besar dari rata-rata nilai kelas kontrol, dengan selisih 9,16. Dengan demikian dapat disimpulkan bahwa terbukti bahwa Media Kubus Ajaib efektif digunakan dalam pembelajaran.

Untuk mengetahui respons siswa terhadap pembelajaran menggunakan Media Kubus Ajaib, dilakukan pengambilan data melalui anget setelah pembelajaran selesai dilakukan. Jumlah responsden 30 orang dan jumlah pertanyaan 9 item. Adapun rekapitulasi hasil analisis angket respons siswa terhadap pembelajaran menggunakan Media Kubus Ajaib adalah sebagai berikut. 
Tabel 5. Hasil Analisis Angket Respons siswa Terhadap Pembelajaran

\begin{tabular}{|c|c|c|c|c|c|c|c|c|c|}
\hline \multirow{2}{*}{ No. } & \multirow{2}{*}{ Pernyataan } & \multicolumn{2}{|c|}{ SS (4) } & \multicolumn{2}{|c|}{ S (3) } & \multicolumn{2}{|c|}{$\mathrm{TS}(2)$} & \multicolumn{2}{|c|}{ STS (1) } \\
\hline & & $\sum$ & $\%$ & $\sum$ & $\%$ & $\sum$ & $\%$ & $\sum$ & $\%$ \\
\hline 1 & $\begin{array}{l}\text { Kegiatan pembelajaran menggunakan } \\
\text { Media Kubus Ajaib membuat saya } \\
\text { tertarik mengikuti pembelajaran di } \\
\text { kelas pada materi geometri }\end{array}$ & 20 & 67 & 10 & 33 & 0 & 0 & 0 & 0 \\
\hline 2 & $\begin{array}{l}\text { Pembelajaran menggunakan Media } \\
\text { Kubus Ajaib lebih menarik dari pada } \\
\text { pembelajaran hanya menggunakan } \\
\text { lembar kerja saja }\end{array}$ & 17 & 57 & 10 & 33 & 3 & 10 & 0 & 0 \\
\hline 3 & $\begin{array}{l}\text { Saya merasa senang belajar materi } \\
\text { geometri menggunakan Media Kubus } \\
\text { Ajaib }\end{array}$ & 17 & 57 & 13 & 43 & 0 & 0 & 0 & 0 \\
\hline 4 & $\begin{array}{l}\text { Saya aktif dan antusias mengikuti } \\
\text { pembelajaran menggunakan Media } \\
\text { Kubus Ajaib }\end{array}$ & 12 & 40 & 18 & 60 & 0 & 0 & 0 & 0 \\
\hline 5 & $\begin{array}{l}\text { Saya merasa termotivasi mengikuti } \\
\text { pembelajaran menggunakan Media } \\
\text { Kubus Ajaib }\end{array}$ & 12 & 40 & 18 & 60 & 0 & 0 & 0 & 0 \\
\hline 6 & $\begin{array}{l}\text { Pembelajaran menggunakan } \\
\text { Kubus Ajaib menarik dan tidak } \\
\text { membosankan }\end{array}$ & 19 & 63 & 11 & 37 & 0 & 0 & 0 & 0 \\
\hline 7 & $\begin{array}{l}\text { Dengan Media Kubus Ajaib membuat } \\
\text { saya terbantu dalam memahami } \\
\text { materi geometri }\end{array}$ & 12 & 40 & 18 & 60 & 0 & 0 & 0 & 0 \\
\hline 8 & $\begin{array}{l}\text { Belajar matematika dengan } \\
\text { menggunakan Media Kubus Ajaib itu } \\
\text { sangat menyenangkan }\end{array}$ & 17 & 57 & 13 & 43 & 0 & 0 & 0 & 0 \\
\hline 9 & $\begin{array}{l}\text { Belajar menggunakan Media Kubus } \\
\text { Ajaib membuat saya lebih fokus dan } \\
\text { termotivasi untuk belajar }\end{array}$ & 12 & 40 & 13 & 43 & 5 & 17 & 0 & 0 \\
\hline \multicolumn{2}{|r|}{ Jumlah Skor } & 552 & & 372 & & 16 & & 0 & \\
\hline \multicolumn{2}{|c|}{ Total Skor } & \multicolumn{8}{|c|}{940} \\
\hline \multicolumn{2}{|c|}{ Skor Maksimum } & \multicolumn{8}{|c|}{1.080} \\
\hline \multicolumn{2}{|c|}{ Nilai } & \multicolumn{8}{|c|}{87,04} \\
\hline
\end{tabular}

Jika diperhatikan tabel 5, nilai respons siswa terhadap pembelajaran menggunakan Media Kubus Ajaib mencapai 87,04 dengan predikat sangat positif. Jadi dapat disimpulkan respons siswa terhadap penggunaan Media Kubus Ajaib untuk pembelajaran adalah sangat positif. 


\subsection{Disseminate (Penyebaran)}

Diseminasi dilakukan terhadap guru SMPN 3 Tanjung yang peneliti lakukan pada saat kegiatan diskusi dalam rangka evaluasi kegiatan belajar mengajar di SMPN 3 Tanjung.

\section{PENUTUP}

Berdasarkan hasil penelitian, dapat disimpulkan sebagai berikut: (1) Media Kubus Ajaib dinyatakan valid oleh ahli dengan nilai 90,28 kategori sangat baik; (2) Media Kubus Ajaib mendapatkan respons sangat positif dalam uji coba terbatas dengan nilai 85,34; (3) Media Kubus Ajaib mendapatkan respons sangat positif dalam uji efektivitas dengan nilai 87,04 dan dinyatakan efektif digunakan dalam pembelajaran dengan perbedaan selisih ratarata nilai tes kelas eksperimen dan kelas kontrol 9,16; dan (4) Media Kubus Ajaib dapat meningkatkan kemampuan spasial siswa dengan rata-rata kemampuan spasial mencapai 71,33 .

Beberapa saran terkait penelitian ini, diantaranya: (1) Diharapkan kepada guru-guru bidang studi matematika untuk mencoba mengimplementasikan pembelajaran menggunakan Media Kubus Ajaib hasil pengembangan pada penelitian ini karena efektif digunakan dalam meningkatkan kemampuan spasial; (2) Untuk menambah wawasan dalam menggali kemampuan spasial siswa diperlukan penelitian lebih lanjut dengan melakukan penelitian selanjutnya; dan (3) Perlu adanya perubahan kurikulum sekolah yang bisa memasukan kemampuan spasial sebagai salahsatu kemampuan matematika sebagai indikator peningkatan hasil belajar siswa.

\section{REFERENSI}

Chatib, M. (2013). Sekolahnya Manusia: Sekolah Berbasis Multiple Intelligences di Indonesia. Bandung: Kaifa PT Misan Pustaka.

Gunawan. (2015). Model Pembelajaran Sains Berbasis ICT. Mataram: FKIP UNRAM.

Mudlofir, A., \& Rusydiyah, E. F. (2016). Desain Pembelajaran Inovatif: Dari Teori ke Praktik. Jakarta: Rajawali Pers.

Sanjaya, W. (2015). Penelitian Pendidikan: Jenis, Metode, dan Prosedur. Jakarta: Prenadamedia Group.

Sardiman, A. S. (2014). Media Pendidikan: Pengertian, Pengembangan, dan Pemanfaatannya. Jakarta: Rajawali Pers.

Sugiyono. (2015). Metode Penelitian \& Pengembangan. Bandung: ALFABETA. 